Marija Vuković ${ }^{1}$

Ljiljana Miletić ${ }^{2}$ Jelena Maravić ${ }^{3}$
JEL: E41, E47, E51

DOI: 10.5937/industrija44-11952

UDC:336.747.1(497.11)"2002/2015"

Original Scientific Paper

\title{
Estimation of Money Demand Function for Reserve Money in Serbia
}

\author{
Article history: \\ Received: 11 September 2016 \\ Sent for revision: 1 October 2016 \\ Received in revised form: 27 November 2016 \\ Accepted: 1 December 2016 \\ Available online: 30 December 2016
}

\begin{abstract}
This paper examines the relevance of the function of demand for reserve money in the Republic of Serbia in the period from January 2002 to December 2015 (168 monthly observations). Our research showed positive and statistically significant coefficients for variables gross domestic product at constant prices and deposit interest rates. The model showed the expected and significant sign for inflation that is a negative correlation between inflation and demand for reserve money. The research results suggest that increase of expected inflation by $1 \%$, with the other variables unchanged, will reduce demand for reserve money for 754 million RSD. The higher the expected inflation, the more pronounced is the recourse to real forms of assets.
\end{abstract}

Keywords: demand for reserve money, inflation, gross domestic product.

\section{Ocena funkcije tražnje za primarnim novcem u Republici Srbiji}

Apstrakt: U ovom radu ispitana je relevantnost funkcije tražnje za primarnim novcem u Republici Srbiji, u periodu od januara 2002.godine do decembra 2015.godine (168 mesečnih observacija). Istraživanje je pokazalo pozitivne $i$ statistički značajne koeficijente uz promenljive bruto društvenog proizvoda $i$ pasivne kamatne stope na depozite. Model je pokazao očekivani i značajan predznak za inflaciju, odnosno negativnu korelaciju između inflacije i tražnje

\footnotetext{
${ }^{1}$ Novi Sad Business School, Serbia, vlahmari@uns.ac.rs

${ }^{2}$ University Educons, Sremska Kamenica, Faculty of Project and Innovation Management, Belgrade, Serbia

${ }^{3}$ National Bank of Serbia

Industrija, Vol.44, No.4, 2016 
Vuković M. et al.: Estimation of Money Demand Function for Reserve Money...

za primarnim novcem. Rezultati istraživanja sugerišu da će pri porastu očekivane inflacije od 1\%, i ostalim nepromenjenim varijablama, doći do smanjenja tražnje za primarnim novcem za 754 miliona dinara. Što je veća očekivana inflacija, veća je tražnja za drugim oblicima aktive.

Ključne reči: tražnja za primarnim novcem, inflacija, bruto društveni proizvod.

\section{Introduction}

Demand for reserve money $\left(\mathrm{M}_{0}\right)$ plays a key role in macroeconomic analysis, particularly in the selection of appropriate monetary and fiscal strategy. Consequently, numerous authors conducted a number of theoretical and empirical researches in the world over the last decade (Gali \& Gerter, 2007; Gali, 2008; Hemantha \& Ekanayake, 2012; Eickmeier, Gambacorta \& Hofmann, 2013; de Grawe \& von Heideken, 2013). Goals and channels of reserve money creation are one of the most challenging questions of monetary policy and economy. Its importance usually increases in the periods of instability of financial markets and slow economy growth (recession). Reserve money creation does not just define deposits multiplication process, but have influence on all other economic variables (interest rates, inflation, employment, gross domestic product - GDP, growth, liquidity). Reserve money is an input for secondary money emission that is created through banks credit channels and supply of loans to non-financial sector. Flows of reserve money creation are evident at central banks' balance sheet assets, and they are different from country to country.

This paper estimates the determinants of demand for $M_{0}$ in the Republic of Serbia, according to the methodology of monetary strategy of the European Central Bank (Hall, Swamy, Tavlas, 2012). The first step is to check if it is possible to estimate demand for reserve money and which variables have an influence on it. Movements and trends of variables were analyzed, correlations between them in order to evaluate the whole model and to give the best possible estimate.

In extensive literature two aspects are especially emphasized as relevant for the modeling and estimation of demand for $\mathrm{M}_{0}$ : (i) the choice of variables, (ii) the choice of the methodological framework. Incorrect choice of variables and methodological frameworks are causes of poor empirical results. Research has shown that a multiple regression model is appropriate (Leeper, 2013).

The objective of this paper is to compare the estimated and original series of the demand for $\mathrm{M}_{0}$, and determine if there are significant discrepancies. 
Vuković M. et al.: Estimation of Money Demand Function for Reserve Money...

This paper is organized as follows. The first section provides an overview of the literature that is relevant for the analysis of demand for $M_{0}$. In the second part of this paper, in order to identify possible factors that influence the demand for $M_{0}$, empirical data analysis was conducted. The implications of the empirical results are presented in the third part of this paper. The last part of the paper presents some concluding remarks.

\section{Review of literature}

In the literature, there are several approaches that are exploring relationship between fiscal deficits and inflation.

In the first approach, the central bank takes the central role of deficit financing (Sargent, Wallence, 1981). If the fiscal authority undertakes the first move, there is a monetary policy to maintain the balance of intertemporary budget ("unpleasant monetary arithmetic"). It can be done in two ways, and the choice is very difficult. Namely, to loosen its policy in the short term, to avoid high inflation in the long term or to tighten its policy today on account of the unavoidable future growth of inflation. Tighter monetary policy increases the real interest rate (and therefore debt servicing costs), slows the economy (deterioration of the deficit through automatic stabilizers), and reduces the monetary income. Fiscal deficit increases and eventually may become unsustainable. So, sooner or later, the fiscal imbalance must be financed through the monetary system. Generally, the dominance of the fiscal regime inevitably involves intertemporal positive correlation between fiscal deficits and inflation. First of all, it is causality from the fiscal deficit to inflation.

The second approach analyzes the relationship between fiscal deficits and inflation through the study of the effects of inflation on the public debt and the real interest rate. Because economy cannot sustain additional tax burden, the government is using inflation to reduce the amount of accumulated public debt. The level of public debt takes on a historical level almost everywhere in the world, and numerous authors, according to this approach, estimate fiscal inflation (Cochrane (2011); Leeper, Walker (2012), Sims (2011)). Fiscal theory implies that if the increase in public debt was not accompanied at the same time with achieving a budget surplus, inflation will follow immediately or in the near future, depending on the maturity structure of debt (De Graeve, von Heideken, 2013). However, despite an unfavorable current situation in terms of fiscal and actual inflation, its expectations are low according to some authors, who reject both concerns for fiscal inflation (Gali, 2013).

According to the third approach, causality comes primarily from the effects of fiscal deficits on inflation. However, the mechanism that higher inflation helps 
Vuković M. et al.: Estimation of Money Demand Function for Reserve Money...

the closing of the fiscal deficit is different. Namely, inflation reduces the real amount of public debt and makes possible rapid debt repayment through higher interest rates (Viera, 2000; Catala, 2003; Woodford, 2012).

Identifying fiscal inflation is very difficult. There are at least three obstacles that make identification difficult. First, fiscal shocks do not occur in isolation, but typically come at a time when the economy is affected by other shocks. Another obstacle is the formalization of the fiscal policy. Modern researches have made great progress in the modeling of fiscal policy. On the one hand, the models are more complex and include budget constraint (Davig, Leeper, Walker, 2011), the mechanism spillover (Bianchi, llut, 2012), or instability variables over time (Fernández-Villaverde, Kuester et al., 2011). On the other hand, assumptions about fiscal policy objectives are usually ad hoc and models often fail to include important aspects such as the maturity structure of debt. The third factor that makes it difficult to identify the fiscal crisis is the econometric forecasting of expectations (Blanchard, Lorenzoni, Huillier, 2013; Leeper, Walker, Yang, 2013).

\section{Research Hypothesis}

Depending on the identified determinants of the demand for $M_{0}$ in the analyses we have set three hypotheses.

According to the quantitative theory of money, GDP increases by $1 \%$, on average, lead to the reduction of $\mathrm{M}_{0}$ from $0.5 \%$ to $1 \%$ (Friedman, 1956). This means that a high degree of correlation between these two variables reflects a satisfactory degree of rationalization of money operations (Hall, Swamy \& Tavlas, 2012). Thus, the first hypothesis is a high correlation between $M_{0}$ and changes in real GDP.

Though historical evidence suggests a high correlation between changes in reserve money $-M_{0}$ and price changes, Friedman noted that this relationship "does not say anything about the direction of influence" (Friedman, 1956). However, the diversity of monetary arrangements (the gold standard, the flexibility of the exchange rate regimes with and without central bank) allows for significant changes in demand for $M_{0}$ also a necessary and sufficient condition for essential changes in the general price level. Therefore, the second hypothesis aims to show that there is a relationship between changes in $\mathrm{M}_{0}$ and price changes over the business cycle, where direction of impact is less clear.

In literature, monetization is often used for observing the phenomenon of increasing share of reserve money in GDP. Using this ratio as an indicator of the degree of monetization, previous studies shows that positive deposit 
Vuković M. et al.: Estimation of Money Demand Function for Reserve Money...

interest rate is the basic precondition for significant financial development (McLoughlin \& Kinoshita, 2012). This can be explained by the following mechanisms: (i) negative interest rates tend to discourage households from making new banking deposits (Townsend \& Ueda, 2010); and (ii) higher real interest rates on deposits induce a substitution effect of holding other forms of financial assets, which is the case in informal credit markets (Kirchner \& van Wijnbergen, 2012). In both mechanisms, real deposit interest rates appear as one of the main macroeconomic factors that determine the demand for reserve money. That is the reason why the third hypothesis claims that deposit interest rates determinates demand for reserve money, with positive correlation sign.

\section{The econometric methodology and data}

\subsection{Data}

The dependent variable used in the analyses is the real reserve money, while the independent variables that are used are the following: inflation, deposit interest rate and gross domestic product. Data have been downloaded from the web site of National bank of Serbia (web site of National bank of Serbia http://www.nbs.rs/internet/english/80/index.html, 2016).

Definitions of monetary aggregates are harmonized with the System of National Accounts and monetary and financial statistics used by the International Monetary Fund in presenting data for all countries in the International Financial Statistics publication. Dinar reserve money, i.e. reserve money according to the narrow definition, consists of currency in circulation, bank dinar reserves and dinar reserves of other sectors if they are held with the National Bank of Serbia (NBS). Reserve money, according to broader definition includes also foreign currency deposits of banks with the National bank of Serbia. In this paper, we have used broader definition of reserve money.

When we talk about demand for money, we are talking about money in the real term. In our case, demand for reserve money we have calculated while deflating nominal

The study examines the demand for money in the period from January 2002 to December 2015 (168 monthly observations). The demand for money in this case is the demand for reserve money $-M_{0}$. Gross domestic product is used as an indication the volume of transactions in the economy and quarterly gross domestic product data have been disaggregated on a monthly basis, using data for series of industrial products as a referent data series. As a 
Vuković M. et al.: Estimation of Money Demand Function for Reserve Money...

proxy for expected inflation was used the growth of consumer prices index and before 2007 retail price index was used it presents yield of alternative forms of assets. In the model we used weighted average interest rate on dinar deposits of nonfinancial corporations and households, as a measure of the rate of return on money as transaction medium (own rate of money).

Weighted average interest rate is calculated based on the data on interest rates on particular types of deposits and the stock of deposits at the end of the given month, on a monthly basis. As of September 2010, NBS statistic of loan and deposit interest rates is fully aligned with the European Central Bank regulations (ECB regulations).

Dummy variable with a non-zero value on February 2009, was included in the model. It represents the impact of the economic crisis on the behavior of economic agents. Figure 1 shows movement of main variables, real and nominal deposit money.

Figure 1. Movements of Real and Nominal deposit money

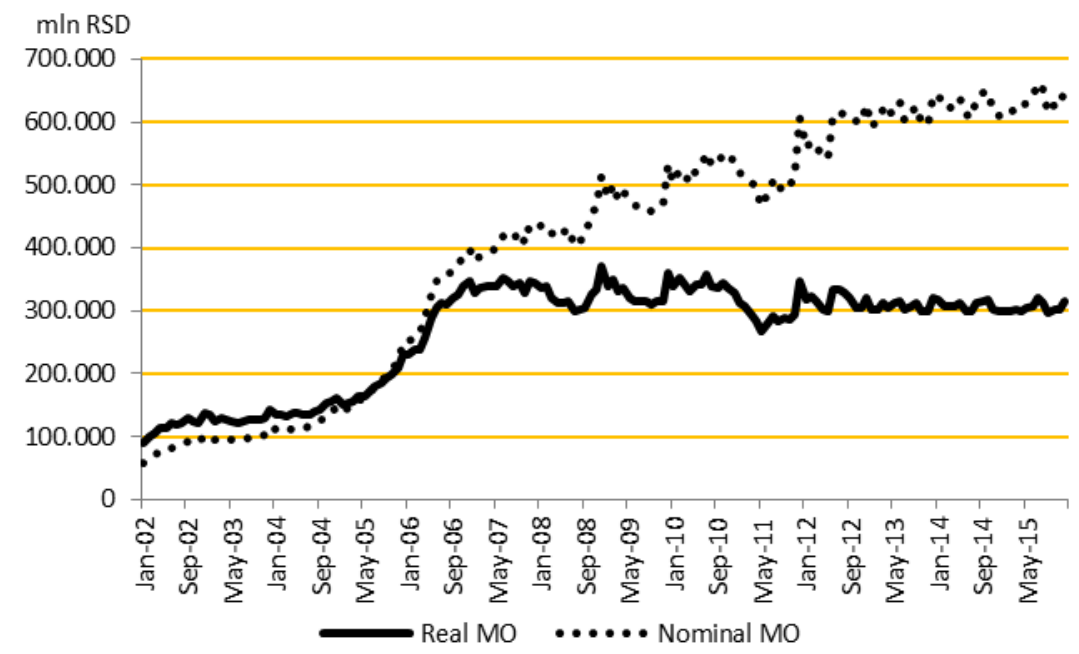

Source: authors

Until July 2005, real reserve money was above its nominal level. As long as nominal money supply is stable, positive inflation rate moves real money supply downward. In these periods restrictive monetary policy was on the scene. For the period July-September 2005 real reserve money was on the same level as its nominal term, and after that real reserve money has started to decrease bellow its nominal level. 
Vuković M. et al.: Estimation of Money Demand Function for Reserve Money...

Higher amounts of nominal reserve money were followed by inflation oscillations, and that is the reason why real reserve money has stayed below its nominal value. That is the consequence of expansive monetary policy. Starting from July 2012 relationship between these two variables is stable, but real reserve money is still two times lower that it's nominal level. Increasing trend of money supply is positive from the point of conduction of the monetary policy. The best monetary policy is the one that enables stabile tendency growth of money supply no matter the situation of the economy.

Figure 2 shows movements of deposit interest rate and inflation. Inflation rate has downward trend trough years, and in 2014 consumer prices has recorded increase just of $1.7 \%$. Such a low level of inflation has not been recorded in the last 40 years in Serbia (in 2006 retail price index was 6.6\%).

Figure 2. Movements of Deposit interest rates and inflation $y-0-y$

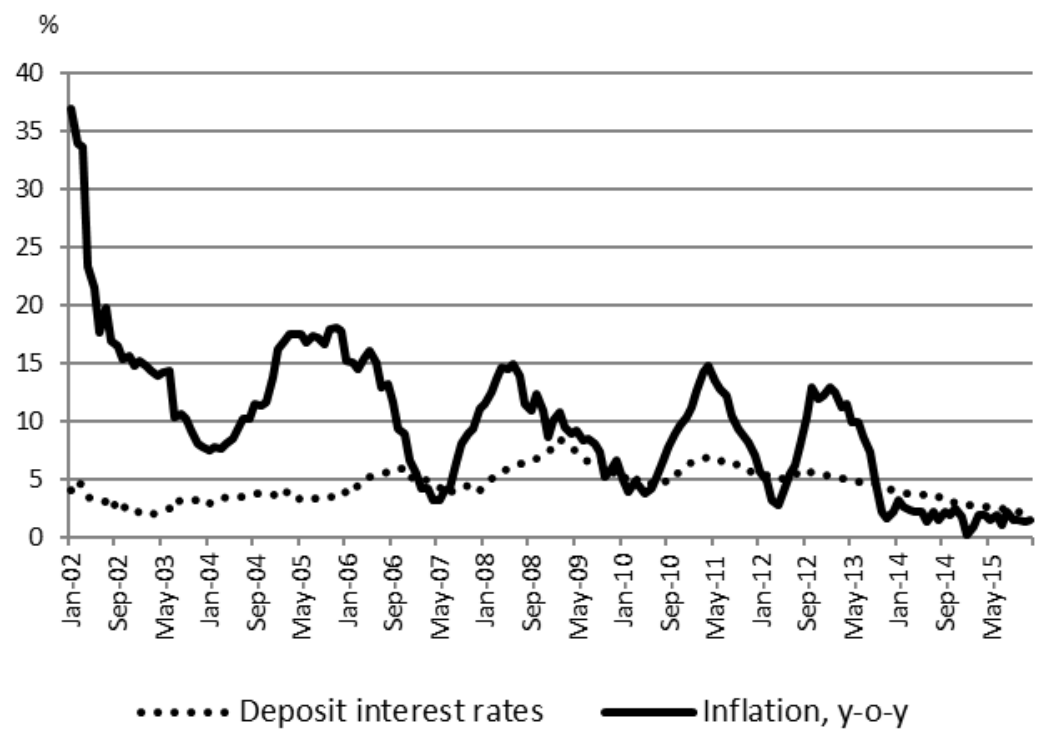

Source: authors

Figure 3 shows movements of Industrial production index. The movement of industrial production shows high seasonal characteristics, such as seasonal lover level of production in February every year.

Figure 4 shows movements of gross domestic product, in constant prices. In the period 2002-2006 high gross domestic product growth was recorded. In 2008 economy was heated up due to high credit growth, increase of real wages and high trade and balance of payment deficit. In that period, economy 
Vuković M. et al.: Estimation of Money Demand Function for Reserve Money...

growth was not sustainable in the long run. In 2009, gross domestic product started to fall, due to slowing of economic activity which was continued in the following years (2010-2011).

Figure 3. Movements of Industrial production $(2015=100)$

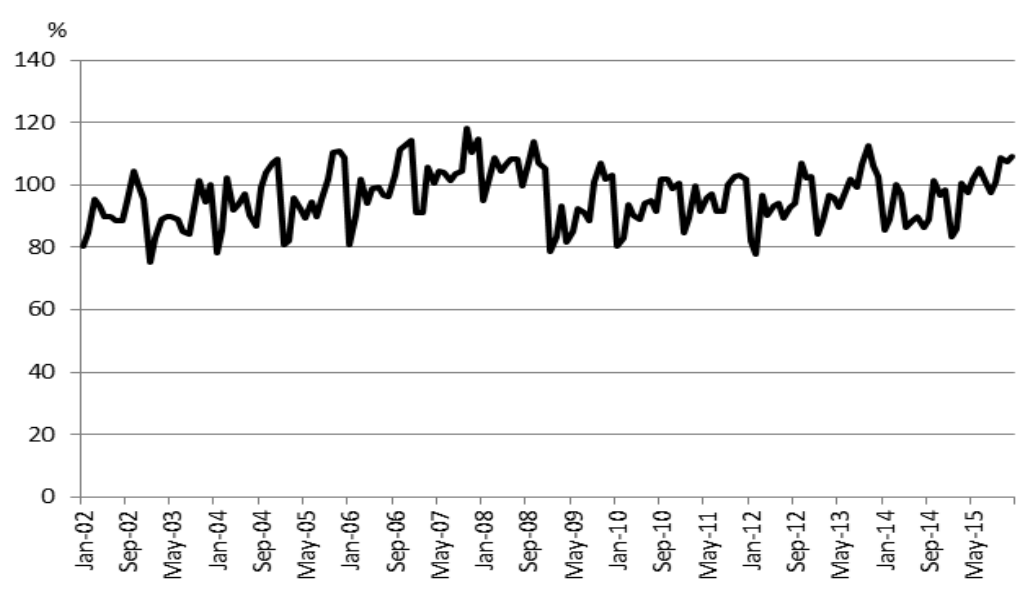

Source: authors

Due to expansive monetary policy, inflation has started to rise from the beginning of 2010. Starting from 2012 gross domestic product has started again to record positive growth rates.

Figure 4. Movements of GDP, at constant

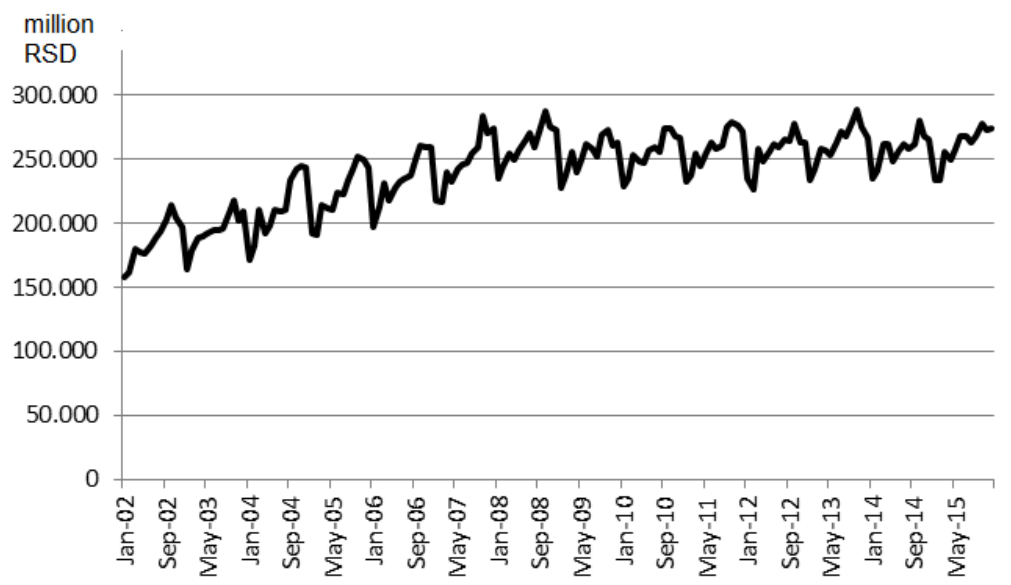

Source: authors 
Vuković M. et al.: Estimation of Money Demand Function for Reserve Money...

Table 1 (Correlation matrix) shows value of correlation coefficient close to 1 shows high level of positive linear correlation between two variables. From Table 1 of the observed series we have noticed that the level of real reserve money is most positively correlated with the level of gross domestic product (correlation coefficient $=0.8$ ). It is evident that the real reserve money is also positively correlated with deposit interest rate (correlation coefficient $=0.6$ ), while negatively correlated with growth of consumer prices, which is taken as an approximation of expected inflation (correlation coefficient $=-0.6$ ).

Table 1. Correlation matrix

\begin{tabular}{|l|c|c|c|c|}
\hline \multicolumn{1}{|c|}{ Correlation } & $\begin{array}{c}\text { Expected } \\
\text { inflation }\end{array}$ & $\begin{array}{c}\text { Gross } \\
\text { domestic } \\
\text { product }\end{array}$ & $\begin{array}{c}\text { Real } \\
\text { reserve } \\
\text { money }\end{array}$ & $\begin{array}{c}\text { Deposit } \\
\text { interest } \\
\text { rate (2010) }\end{array}$ \\
\hline Expected inflation & 1.0 & -0.6 & -0.6 & 0.1 \\
\hline $\begin{array}{l}\text { Gross domestic product } \\
\text { (2010) }\end{array}$ & -0.6 & 1.0 & 0.8 & 0.4 \\
\hline $\begin{array}{l}\text { Real reserve money at the } \\
\text { end of the period }\end{array}$ & -0.6 & 0.8 & 1.0 & 0.6 \\
\hline Deposit interest rate & 0.1 & 0.4 & 0.6 & 1.0 \\
\hline
\end{tabular}

Source: authors.

The signs of the correlation coefficients are logical, and confirm the validity of expectations of the the hypothesis stated on the beginning of this working paper.

\subsection{Estimation of data appropriateness}

The original idea was to test the co-integration relationship between the observed series by using Johansen's co-integration test (Johansen, 2002; Lutkepohl, 2005). In the literature Johansen's co-integration test is used to detect long run co-integration relationship between variables. Prerequisite for the conduction of Johansen's co-integration test is that all used data series have to have the same (not zero) order of integration. Before making an appropriate model, we have analyzed the time series data that were considered to be relevant in this case.

Table 2 shows basic statistical parameters of the following variables: Real reserve money, Consumer prices y-0-y growth rate, Gross domestic product and Deposit interest rate. 
Vuković M. et al.: Estimation of Money Demand Function for Reserve Money...

Table 2. Basic statistical parameters of the variables, period January 2002 December 2015

\begin{tabular}{|l|c|c|c|c|}
\hline \multirow{2}{*}{ Parameters } & \multicolumn{4}{c|}{ Variables } \\
\cline { 2 - 5 } & $\begin{array}{c}\text { Real reserve } \\
\text { money }\end{array}$ & $\begin{array}{c}\text { Rate of } \\
\text { consumer } \\
\text { price }\end{array}$ & $\begin{array}{c}\text { Gross } \\
\text { domestic } \\
\text { product }\end{array}$ & $\begin{array}{c}\text { Deposit } \\
\text { interest } \\
\text { rate }\end{array}$ \\
\hline Mean & 265893.7 & 9.7 & 240793.2 & 4.5 \\
\hline Median & 304543.0 & 9.3 & 249142.5 & 4.4 \\
\hline Maximum & 370546.0 & 36.9 & 288430.0 & 8.4 \\
\hline Minimum & 90775.0 & 0.1 & 157594.0 & 1.9 \\
\hline Standard Deviation & 82684.7 & 6.2 & 30026.3 & 1.5 \\
\hline Skewness test & -0.9 & 1.1 & -0.8 & 0.3 \\
\hline Kurtosis test & 2.1 & 6.0 & 2.7 & 2.4 \\
\hline $\begin{array}{l}\text { Mean/Standard } \\
\text { Deviation*100 }\end{array}$ & 321.6 & 156,5 & 801.9 & 300.0 \\
\hline
\end{tabular}

Source: authors.

Mean is the average value of the series obtained by adding up the series and dividing by the number of observations, and Median is the middle value (or average of the two middle values) of the series when the values are ordered from the smallest to the largest.

According the results in Table 2 Real reserve money has two peaks in distribution (measure of dispersion or spread in the series) with higher grouping of the results to the right side, and varies in range (90776,0$370546,0)$ with mean value 265893,7 and slightly higher median $(304543,0)$. Rate of consumer prices have peaked distribution that is slightly right tailed and varies in wide range $(0,1-36,9)$ with mean value 9,7 and slightly lower median $(9,3)$. Gross domestic product has peaked distribution that is slightly left tailed and varies in wide range $(157594,0-288430,0)$ with mean value 240793,2 and slightly higher median $(249142,5)$. Deposit interest rate have peaked distribution that is slightly right tailed and varies in wide range $(1,9$ $8,4)$ with mean value 4.5 and slightly lower median $(4,4)$.

According Skewness test (Coefficient of asymmetry) shows a measure of asymmetry of the distribution of the series around its mean Deposit interest rate and Consumer prices have positive asymmetry in the data, with a longer right tail of distribution $(0,3 ; 1,1)$. Real reserve money and gross domestic product have negative asymmetry in the data $(-0,9 ;-0,8)$ what implies that the distribution has a long left tail.

Kurtosis test (Coefficient of flatness) shows measures the peakedness or flatness of the distribution of the series. All the series except consumer prices 
Vuković M. et al.: Estimation of Money Demand Function for Reserve Money...

has Kurtosis less than 3 , and their distributions are flat relative to the normal (platykurtic). The Kurtosis test of Rate of consumer prices exceeds 3 (6), it means that the distribution is peaked (leptokurtic) relative to the normal; the distribution is peaked (leptokurtic) relative to the normal.

Table 3. shows the results ADF tests. We examine whether observed data series are stationary or non-stationary using Augmented Dickey-Fuller (ADF) unit root test. Test was run in econometric software EViews, where it gives automatically critical value of ADF test; test is calculated automatically by taking into account all available information (number of observations, number of variables, number of legs, etc.). The results $t$ is shown critical value as well as calculated value of ADF test. ADF test is used to test the null hypothesis of whether a unit root is present in a time series sample. If calculated value of ADF test is lower than critical value, we can conclude that data series is stationary (no unit root). In the opposite situation, we have to detect is there one or more unit roots (Mladenović, Nojković, 2009).

Table 3: Augmented Dickey-Fuller unit root test, period January 2002 December 2015

\begin{tabular}{|l|c|c|c|c|}
\hline \multirow{2}{*}{ Variable } & \multicolumn{2}{|c|}{ Level } & \multicolumn{2}{c|}{$\mathbf{1}^{\text {st }}$ difference } \\
\cline { 2 - 5 } & $\begin{array}{c}\text { Value of t } \\
\text { distribution }\end{array}$ & Probability & $\begin{array}{c}\text { Value of t } \\
\text { distribution }\end{array}$ & Probability $^{*}$ \\
\hline $\begin{array}{l}\text { Year-on-year rate of } \\
\text { consumer price }\end{array}$ & -2.66 & 0.09 & -10.13 & 0.00 \\
\hline $\begin{array}{l}\text { Gross domestic product } \\
\text { at constant prices, } \\
\text { reference year 2010 }\end{array}$ & -2.48 & 0.12 & -3.45 & 0.011 \\
\hline $\begin{array}{l}\text { Real reserve money at } \\
\text { the end of the period }\end{array}$ & -2.06 & 0.26 & -14.87 & 0.00 \\
\hline Deposit interest rate & -1.66 & 0.45 & -7.31 & 0.00 \\
\hline $\begin{array}{l}\text { Index of industrial } \\
\text { production }\end{array}$ & -3.50 & 0.01 & & \\
\hline
\end{tabular}

Source: authors.

On the results in Table 3 we can see that most of the variables are nonstationary, i.e. data series have the first order of integration (one unit root).. Only the annual growth rate of consumer prices (CPI) proved to be stationary on $10 \%$ probability. Index of industrial production is definitely stationary on $1 \%$ probability.

\subsection{Model}

The size of the fiscal deficit is determined by fiscal policy, while its financing is the responsibility of monetary policy, i.e. central bank is responsible for 
Vuković M. et al.: Estimation of Money Demand Function for Reserve Money...

financing fiscal deficit. If the fiscal deficit is financed by issuing reserve money and /or borrowing, the following equations stands 1 (Svaljek, 2003, p.122):

$$
P B_{\mathrm{t}}+i^{D} B_{\mathrm{t}-1}^{p}+i^{L} B_{\mathrm{t}-1}^{N} E=\Delta B^{p}+\Delta L^{\mathbb{N}} E+\Delta M_{0}
$$

with:

$P B$ - the primary balance of the public sector;

$i^{D}$ - nominal interest rate on domestic public debt;

$i^{L}-$ interest on external debt;

$B^{\text {p }}$ - public debt of domestic private sector;

$L^{\mathbb{N}}$-stock of net foreign public debt (foreign debt decreased for foreign exchange reserves);

$E$ - nominal exchange rate.

The left side of the identity presented net expenses (expenses - taxes) of the public sector which are financed by borrowing or issuing money.

Changes of reserve money are the consequence of the one or more factors: (i) changes of foreign exchange reserves (due to central bank operations foreign transactions), (ii) changes of public debt at central bank (trough operations on open market and/or direct lending to the government, (iii) changes in net lending to financial sector ("expected" direct lending to banks). According to above stated, the change in the quantity of money can be expressed with the equation 2 (Svaljek, 2003, p.123):

$$
M_{0_{\mathrm{t}}}-M_{0_{\mathrm{t}-1}}=\left(B_{\mathrm{t}}^{e}-B_{\mathrm{t}-1}^{e}\right)+\left(K_{\mathrm{t}}^{e}-K_{\mathrm{t}-1}^{e}\right)+\left(F_{\mathrm{t}}^{e}-F_{\mathrm{t}-1}^{e}\right) E_{\text {o }}
$$

with: $M_{0}$ - quantity of reserve money,

$B^{c}$ - quantity of securities held by the central bank,

$K^{C}$-issued loans from the primary issue and

$F^{c}$-balance of foreign exchange reserves of the central bank.

In order to analyze determinants of the demand for reserve money, it is assumed that the reserve money is the function of inflation rate, deposit interest rate and GDP. Consequently, the (Svaljek, 2003, p.127):

In next equation (3) demand for reserve money $\left(M_{0}\right)$ is expressed in the form of a share in nominal GDP. 
Vuković M. et al.: Estimation of Money Demand Function for Reserve Money...

$M_{0} /(P Y)=f\left(\pi, i^{D V}, i^{D O}\right)$

with:

$\mathrm{M}_{\mathrm{o}}$ - the demand for primary money

PY - primary money is shown here as a proportion of the nominal GDP

$\pi$ - the inflation rate in the country, defined as $\pi=\left(P_{t}-P_{t-1}\right) / P_{t-1}$

$i^{D V}$ interest rates on demand deposits

${ }_{i}^{D o}$ interest rates on time deposit.

The equation (3) can be used to measure the impact of changes in inflation rates, deposit interest rates and GDP on real money demand and the impact of these changes on the revenue that the public sector can expect.

\subsection{Empirical results}

Reserve money in the Republic of Serbia consists of two basic components, currency outside banks and allocated reserves. It can be seen that there is a functional relationship between the real money supply and reserve money, which justifies the estimation of the reserve money equation. The econometric estimation of the function of demand for reserve money is done by use year rise in retail prices, as inflation indicator by 2007, using the following variables:

- $\quad M_{0 \text { real }}$ - Real reserve money at the end of the period

- $\quad \mathrm{CPI}$ - Index of consumer price, year-on-year growth rate

- GDP -Gross domestic product at constant prices, reference year 2010

- $\quad$ IR - Deposit interest rate,

- $\quad \mathrm{FEB}_{2009}$ - A dummy variable February 2009.

Econometric analysis was performed by the method of Ordinary Least Squares (OLS). Real reserve money was defined as dependent variable, while all other variables were used as independent.

Parameters in the function of the demand for reserve money are estimated by the econometric model as follows. The equation (4) for the demand for reserve money in Republic of Serbia was developed based on the equation (3):

$$
M_{0 \text { Real }}=C P I_{t}^{\alpha_{1}} G D P_{t}^{\alpha_{2}} I R_{t}^{\alpha_{3}} F E B_{2009}^{\alpha_{4}}
$$

Estimated equation of the demand for reserve money, using Ordinary Least Squares, for the period 2002-2015 gave the following results (equation 4): 
Vuković M. et al.: Estimation of Money Demand Function for Reserve Money...

Details of the estimated model are shown in Table 4. The linear regression model is presented, estimated in econometric software EViews. As a dependent variable Logarithm of Real reserve money (log Moreal) was used; Ordinary Least Squares method was conducted for the period January 2002December 2015 (168 observations).

According to the results shown in Table 4, it is evident that the equation (4) for the estimation the demand for reserve money has the good properties of econometric estimates. The values of the coefficient of determination $\left(R^{2}=0.82\right)$ and the corrected coefficient of determination (Adjusted $R$ squared $=0.81$ ) are high, indicating that the proportion of the unexplained variance in demand for base money at about $1 \%$. The standard error of estimates is low $1 \%$. The resulting equation represents a real demand for real reserve money. Coefficients of all the variables have high values of $t$ statistics, and extremely high significance. The coefficient of the variable Logarithm of gross domestic product, which also shows the income elasticity of Demand for real reserve money is high at 0.98 , which is consistent with the quantity theory of money and the first set of research hypotheses. When there is a GDP growth by $1 \%$, the demand for reserve money will increase by $0.98 \%$, unchanged in terms of inflation and interest rates, which indicates a satisfactory degree of rationalization cash business. To the coefficients of the other variables are interpreted as elasticity (since they logarithms) we use a formula such as the current odds share with the average of the corresponding quotient and original series Real reserve money.

Table 4. Econometric estimation the demand for reserve money in the Republic of Serbia (January2002 to December 2015)

\begin{tabular}{|l|c|c|c|c|}
\hline \multicolumn{1}{|c|}{ Variable } & Coefficient & $\begin{array}{c}\text { Standard } \\
\text { Error }\end{array}$ & $\begin{array}{c}\text { Students t- } \\
\text { distribution }\end{array}$ & Probability \\
\hline $\begin{array}{l}\text { Year on year rate of } \\
\text { consumer price }\end{array}$ & -0.03 & 0.00 & -13.23 & 0.00 \\
\hline $\begin{array}{l}\text { Logarithm of Gross } \\
\text { domestic product }\end{array}$ & 0.98 & 0.00 & 265.49 & 0.00 \\
\hline Deposit interest rate & 0.11 & 0.01 & 12.10 & 0.00 \\
\hline $\begin{array}{l}\text { A dummy variable } \\
\text { February 2009 }\end{array}$ & 0.23 & 0.08 & 2.95 & 0.00 \\
\hline
\end{tabular}

\begin{tabular}{|l|c|l|c|}
\hline Coefficient of determination & 0.82 & Mean dependent variable & 12.43 \\
\hline $\begin{array}{l}\text { Adjusted coefficient of } \\
\text { determination }\end{array}$ & 0.81 & $\begin{array}{l}\text { Standard deviation of } \\
\text { dependent variable }\end{array}$ & 0.39 \\
\hline Standard error of regression & 0.17 & Akaike info criterion & -0.71 \\
\hline Summa squared residual & 4.62 & Schwarz criterion & -0.63 \\
\hline Logarithm of likelihood & 63.46 & $\begin{array}{l}\text { Durbin-Watson test of } \\
\text { autocorrelation }\end{array}$ & 0.27 \\
\hline
\end{tabular}

Source: authors. 
Vuković M. et al.: Estimation of Money Demand Function for Reserve Money...

So we get in Table 4 that the growth in deposit interest rates by $1 \%$, increase the demand for reserve money for 65427 million RSD.

The equation (5) for rating of demand for reserve money in Republic of Serbia was obtained by using the regression analysis of the data for period 20022015.

$\log M_{0 . y_{e a l}}=-0.03 C P I_{t}+0.98 \log G D P_{t}+0.11 I R_{t}+0.23 F E B_{2009}$

Based on equation (5) was made chart (Figure 5) for comparison the movements of the original and estimated demand for reserve money.

Figure 5: Trends in the original and estimated data series of the demand for reserve money

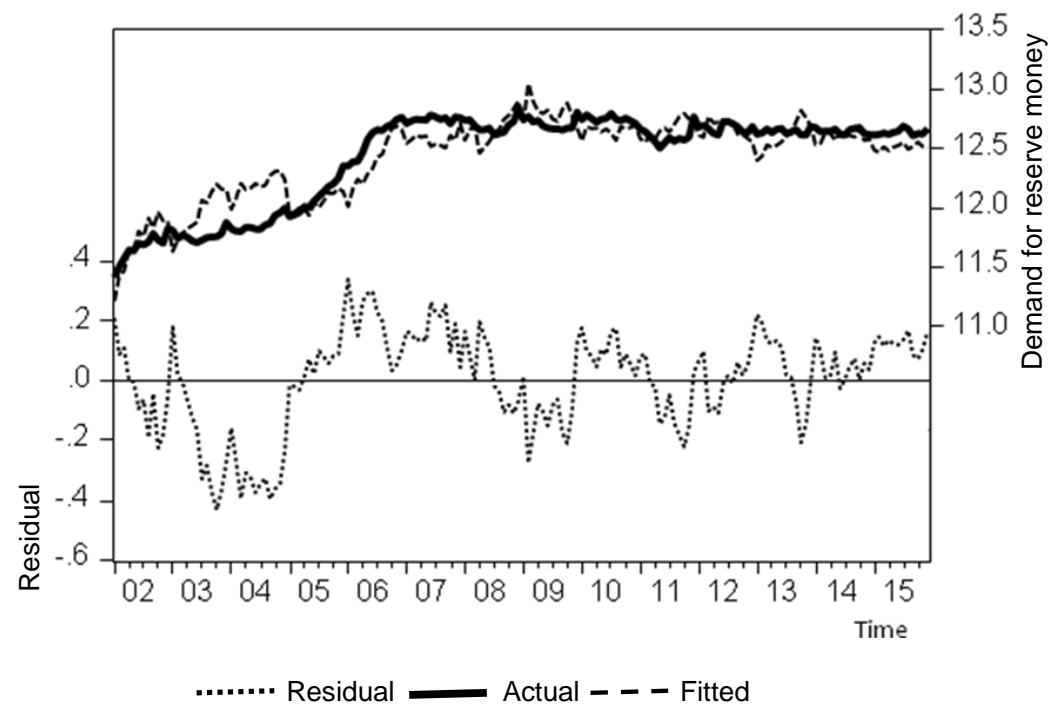

Source: authors

Figure 5 once again suggests good quality of the estimated model. It can be concluded that the estimated series does not deviate much from the original that is shown by the movements and amounts of residuals (left side). 
Vuković M. et al.: Estimation of Money Demand Function for Reserve Money...

\section{Concluding remarks}

The demand for reserve money plays a key role in macroeconomic analysis, particularly in the selection of appropriate monetary and fiscal strategy. The stable demand function for reserve money means that the amount of reserve money identifies several key variables that connect the public and the real sector of the economy.

This paper identified several very relevant variables that influence demand for reserve money. It is important to analyze the characteristics of time series data thoroughly before selecting appropriate assessment techniques, as it is done in the paper. An important contribution of this work comes from the use of monthly observations. The model based on high frequency data is able to identify the impact of the measures taken by the government or developments in the economy on the demand for reserve money. Stable demand function for reserve money will, in turn, help the authorities to efficiently run fiscal and monetary policy.

The results indicate that the model is specified correctly. Estimated demand for reserve money function does not deviate much from the original and is quite stable. The income elasticity is close to one and the other variables have the expected signs. The model showed a negative correlation between inflation and demand for reserve money. The conclusion is that increase of expected inflation by $1 \%$, with the other variables unchanged, will reduce demand for reserve money for 754 million RSD. The higher the expected inflation, the more pronounced is the recourse to real forms of assets.

\section{References}

Blanchard, O., Lorenzi, J.G., \& L'Huillier, J.P. (2013). News, Noise, and Fluctuations: An Empirical Exploration, American Economic Review, 103(7), pp. 3045-4015.

Eickmeier, S., Gambacorta, L., \& Hofmann, B. (2013). Understanding Global Liquidity. BIS Working Papers, 402,

Fridman, M. (1956). The Quantity Theory of Money: A Restament. In M. Friedman (Ed.), Studies in the Quantity Theory of Money. (pp. 3-21). Chicago: University of Chicago Press.

Gali, J. (2008). Monetary Policy, Inflation, and the Business Cycle: An Introduction to the New Keynesian Framework. Princeton, NJ: Princeton University Press.

Gali, J., \& Gertler, M. (2007). Macroeconomic modeling for monetary policy evaluation. University Pompeu Fabra Department of Economics and Business Working Paper, 1037, 
Vuković M. et al.: Estimation of Money Demand Function for Reserve Money...

Gali, J. (2013). Perceptions and Misperceptions of Fiscal Inflation: A Comment. In A. Alesina \& F. Giavazzi (Eds.), Fiscal Policy alter the Financial Crisis. (pp. 299305). University Chicago Press.

Hemantha, K., \& Ekanayake, J. (2012). The Link Between Fiscal Deficit and Inflation: Do public sector wages matter. ASARC Working Paper, 14,

Johansen, S. (2002). A Small Sample Correction for the Test of Cointegrating Rank in the Vector Autoregressive Model. Econometrica, 70(5), 1929-1961. doi:10.1111/1468-0262.00358

Mladenović, Z., \& Nojković, A. (2009). Zbirka resenih zadataka iz ekonometrije. Beograd: Ekonomski fakultet.

Mcloughlin, C., \& Kinoshita, N. (2012). Monetization in Low and Middle Income Countries. IMF Working Paper, 12(160),

Sargent, T.J., \& Wallence, N. (1981). Some Unpleasant Monetarist Arithmtic. Quarterly Review, Federal Reserve Bank of Minneapolis, 5(3),

Sims, C.A. (2011). Stepping on a Rake: The Role of Fiscal Policy in the inflation of the 1970. European Economic Review, 55, 48-56.

Svaljek, S. (2003). Croatia's capacity to finance its fiscal deficit. Croatian Economic Survey. (pp. 119-154). 5.

Townsend, R.M., \& Ueda, K. (2010). Welfare Gains From Financial Liberalization. International Economic Reviews, 51(3), 553-597.

Viera, C. (2000). Are Fiscal Deficit Inflationary?, Evidence for the EU. Economic Research Paper (London), 00/7, Loughborough University.

Wijnbergen, K. (2012). Fiscal Deficit, Financial Fragility, and the Effectiveness of Government Policies. Tinbergen Institute Discussion Paper, 44(2), TI Timergen Institute Amsterdam.

Woodford, M. (2012). Inflation Targeting and Financial Stability. NBER Working Paper, 17967,

-National bank of Serbia. (2016). . Retrieved from http://www.nbs.rs/internet/english/80/index.html 